\section{APSA Participates in Decade of Behavior}

The Decade of Behavior, an initiative involving more than 50 societies representing the behavioral and social sciences to focus the talents, energy, and creativity of behavioral and social scientists on meeting many of society's most significant challenges, was launched on Capitol Hill on September 25. The initiative's five major themes are improving health, increasing safety, improving education, increasing prosperity, and promoting democracy.

From the time of the initiative's proposal by the American Psycho-

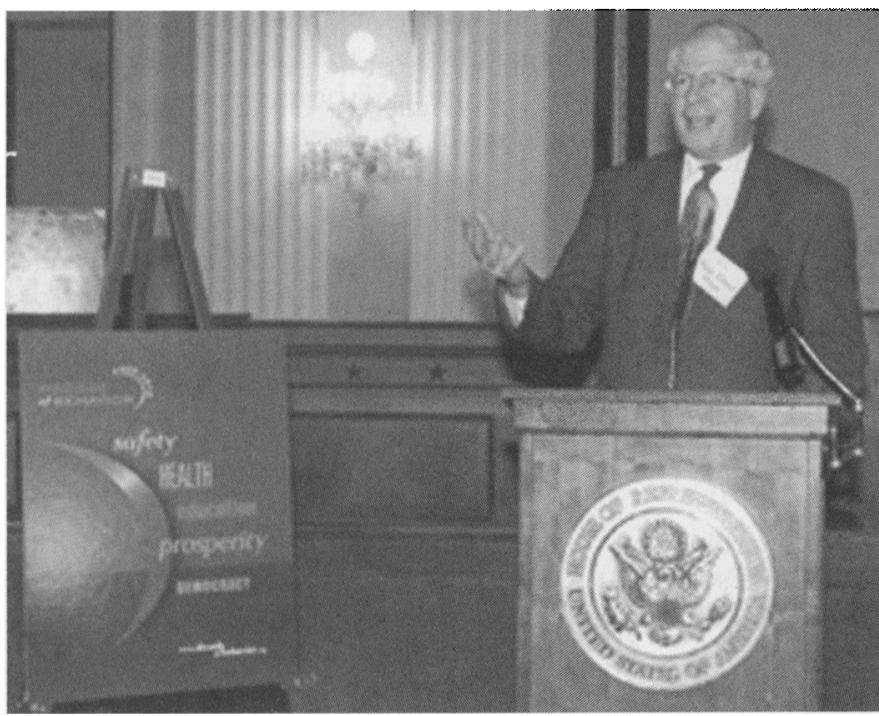

Rep. David Price (D-NC) speaks at the Decade of Behavior opening event. wrote the featured essay on democracy, and it is now available on the APSA web site (www.apsanet.org/ new/schlozman.cfm).

Congressman David Price (D-NC), a political science Ph.D. and former member of the political science department at the University of North Carolina, Chapel Hill, attended the event and read a letter of support from President Clinton. Kent Portney of Tufts University represented political science at the initiative's launch event with an exhibit titled "Integrating Behavioral

Research and Teaching: The Case of Crime and Punishment." Portney, with the assistance of Steve Cohen, director of the Tufts Center for Instructional Technology Assessment, demonstrated use of the crime and punishment multimedia simulation he developed with Jerry Goldman of Northwestern University.

logical Association in 1997, APSA members have played important roles in making it a reality. Donna Behry of Vanderbilt University sought support for the Decade of Behavior from Congress, and Paula McClain of Duke University has represented the political science community on the initiative's national advisory committee. Kay Lehman Schlozman of Boston College
The interactive simulation is designed to help researchers conduct experimental research on sentencing (see http://ase.tufts.edu/polsci/). Research subjects assume the role of a judge who must sentence who have been convicted of felony crimes.

For more information about the decade of behavior, visit www. decadeofbehavior.org/.

\section{Scholar Saver 2000}

The eighteenth edition of the discount brochure was mailed to all individual members of the American Historical Association and APSA in October. A joint publication of the sponsoring associations, Scholar Saver annually lists discounted journals, books, and instructional videos and software of special interest to historians and political scientists. This year's edition contained over 130 listings. If you did not receive your copy of the brochure or would like an additional copy, please contact the APSA membership office at membership@apsanet.org or 202-483-2512.

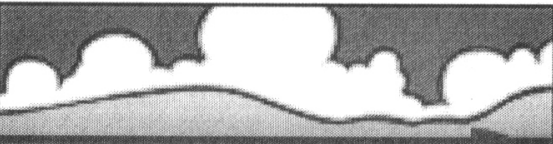 APSA 2001 San Francisco}

APSA will return to the City by the Bay in 2001 and we hope you will participate. The meeting will take place August 30 - September 2 at the San Francisco Hilton and Towers, Renaissance Parc 55, and Hotel Nikko.

\section{Program Co-chairs Edward} Mansfield and Richard Sisson of Ohio State and their Program Committee of 46 Divisions are working to put together a program covering a wider range of topics.

Did you submit a proposal for consideration? If so, you will receive your notification in mid-February via email.

Stay on top of developments surrounding the 2001 meeting via APSANet, the American Political Science Association online. You'll find all the information you need at www.apsanet.org

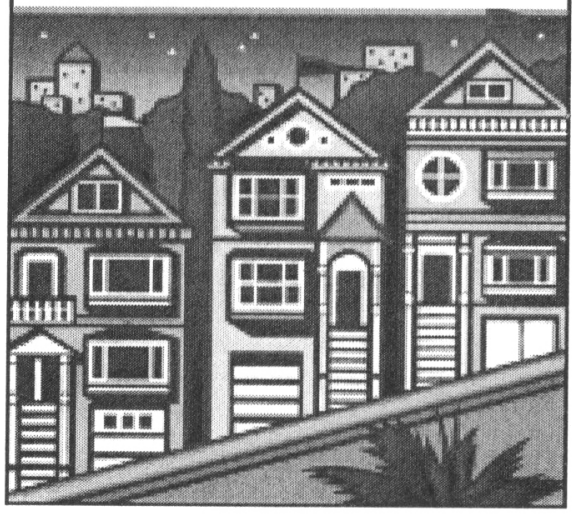

